\title{
TINDAK TUTUR ILOKUSI DALAM ACARA KUIS "WIB" EPISODE 9 JULI 2018 DI NET TV
}

\author{
Dian Rachmawati \\ Dianrachmawati702@gmail.com \\ Pascasarjana \\ Universitas Sam Ratulangi
}

\begin{abstract}
The illocutionary acts is a speech act aiming at not only to convey something but also to do something in the form of speech. Speech is not only used to express something because everyone who speaks has a purpose in every speech. The problem studied in this pragmatic research is forms of illocutionary acts in WIB program in episode 9 July 2018. The purpose of this research is to describe the forms of s illocutionary acts in WIB program in episode 9 July 2018. The method used in this study is qualitative descriptive. Method of data collection using the observation method by using basic techniques, which is observation technique. Furthermore, observation technique is followed with advanced techniques in the form of uninvoluement observation capable of recording, record, and record techniques. The analysis of this research using the method of equalextralingua. Based on the result of the research, it can be concluded that the illocutionary acts in WIB program on July 9, 2018 episode, on Net TV, support Searle concept by discovery five types of illocutionary acts, namely representative, commissive, directive, expressive, and declarative.
\end{abstract}

Keywords: acts of speech, act of speech illocution, quiz WIB

\section{PENDAHULUAN}

Tiap anggota masyarakat selalu melakukan interaksi sosial dalam kehidupan sehari-hari. Pada umumnya, dalam interaksi sosial, mereka menggunakan bahasa sebagai alat komunikasi baik secara lisan maupun tulisan. Penggunaan bahasa tersebut dapat berupa wacana ataupun percakapan yang diwujudkan menggunakan satu, beberapa atau banyak tuturan. Tiap tuturan (dalam wacana atau percakapan) yang disampaikan oleh penutur atau penulis kepada mitra tutur atau pembaca mempunyai makna atau maksud dengan tujuan tertentu. Makna atau maksud dan tujuan tuturan itu disebut dengan menyatakan tindakan. Maksud dan tujuan yang menyatakan tindakan yang melekat pada tuturan itu disebut dengan tindak tutur.

Tindak tutur merupakan analisis pragmatik yaitu cabang ilmu bahasa yang mengkaji bahasa dari aspek pemakaian aktualnya (dalam Widodo dan Sumarta, 2016:51). Menurut Putrayasa (2014:86) tindak tutur adalah kegiatan seseorang menggunakan bahasa kepada mitra tutur dalam rangka mengomunikasikan sesuatu. Makna yang dikomunikasikan tidak hanya dapat dipahami berdasarkan penggunaan bahasa dalam 
bertutur tetapi juga ditentukan oleh aspek-aspek komunikasi secara komprehensif, termasuk aspek-aspek situasional komunikasi. Sedangkan menurut Suwito dalam Putrayasa (2014:85) tindak tutur merupakan gejala individu, bersifat psikologis, dan ditentukan oleh kemampuan bahasa penutur dalam menghadapi situasi tertentu. Tindak tutur dititikberatkan pada makna atau arti tindak, sedangkan peristiwa tutur lebih dititikberatkan pada tujuan peristiwanya. Menurut Hudson dalam Putrayasa (2014:85) tindak tutur (speech acts) adalah ujaran yang dibuat sebagai bagian dari interaksi sosial. Tindak tutur merupakan bagian dari peristiwa tutur dan peristiwa tutur merupakan bagian dari situasi tutur. Ujaran atau tindak tutur dapat terdiri atas satu tindak tutur atau lebih dalam suatu peristiwa tutur dan situasi tutur. Dengan demikian, ujaran atau tindak tutur sangat tergantung dengan konteks ketika penutur bertutur. Tuturan-tuturan itu dapat dimengerti berkaitan dengan kegiatan yang menjadi konteks dan tempat tuturan itu terjadi.

Menurut pandangan Austin (1962) semua tuturan adalah performatif. Maksudnya semua tuturan merupakan sebuah bentuk tindakan dan tidak sekadar mengatakan sesuatu. Berkenaan dengan tuturan, Austin (dalam Widodo dan Sumarta, 2016:51) membedakan tiga jenis tindakan: (1) tindak tutur lokusi adalah tindak proposisi yang berada pada kategori mengatakan sesuatu sebagaimana adanya atau dengan kata lain makna leksikal dan makna sintaksis kalimat bersesuaian. Fokus lokusi adalah makna tuturan yang diucapkan, bukan mempermasalahkan maksud atau fungsi tuturan itu; 2) tindak tutur ilokusi adalah tindak tutur yang mengandung maksud dan fungsi atau daya tuturan untuk melakukan sesuatu. Tindak tutur ilokusi ini biasanya diidentifikasikan dengan kalimat performatif yang eksplisit; 3) tindak tutur perlokusi adalah tindak tutur yang berupa efek atau dampak yang ditimbulkan oleh mitra tutur, sehingga mitra tutur melakukan tindakan sesuai isi tuturan atau dengan kata lain tindak tutur yang dilakukan untuk mendapatkan efek psikologis tertentu. Pada hakikatnya ketiga tindakan dapat dijelaskan sebagai tindakan melakukan sesuatu 'an act of saying something', tindakan untuk melakukan sesuatu 'an act of doing something', dan tindakan untuk memengaruhi 'an act of affecting someone'. Tindakanseperti menyatakan, berjanji, minta maaf, mengancam, meramalkan, memerintah, meminta, dan lain sebagainya merupakan bentuk tindak tutur ilokusi. Tindak ilokusi dapat dikatakan sebagai tindak terpenting dalam kajian dan pemahaman tindak tutur (Nadar, 2009:14). Salah satu bentuk tindak tutur ilokusi yang sering terjadi pada media komunikasi adalah televisi.

Televisi merupakan salah satu media komunikasi bahasa. Setiap stasiun televisi memiliki berbagai macam gelombang siaran dengan program berbeda-beda, mulai dari 
drama (fiksi) dan nondrama (nonfiksi). Program drama (fiksi) seperti tragedi, aksi, komedi, cinta, legenda, dan horor. Sedangkan program nondrama (nonfiksi) diantaranya: musik, talk show, variety show, game show, dan kuis serta berita yang meliputi features, sport, dan news.

Penulis tertarik meneliti salah satu program nondrama televisi, yaitu kuis WIB (Waktu Indonesia Bercanda) yang disiarkan di stasiun televisi NET TV.Ada beberapa keunikan acara WIB ini dibandingkan dengan kuis-kuis di stasiun televisi lainnya. Keunikan yang dimiliki WIB, antara lain: pertama, WIB satu-satunya program yang menampilkan kuis yang dikemas secara komedi yang bisa disebut parodi kuis. Kedua, WIB dipandu oleh pelawak asal Surabaya yang biasa dipanggil Cak Lontong dengan didampingi oleh Nabila Putri atau Fitri Tropika. Cak lontong memiliki gaya berkomedi khas dengan memainkan logika terbalik. Program WIB selalu mengundang satu orang bintang tamu, dan peserta yang bersifat tetap dan bergantian tampil, diantaranya Deny Candra, Bedu, Peppy, Akbar, Agung Hercules, juga ada pengisi acara yang disebut kang Dagang, yang berprofesi sebagai pedagang. Ketiga, WIB merupakan satu-satunya program yang membuat orang jengkel, namun terhibur. Jawaban kuis sering menyalahi kaidah ejaan bahasa Indonesia.Keempat, Program WIB ini dapat ditonton semua umur dan semua kalangan, terkecuali untuk anak yang berumur di bawah 5 tahun. Kuis WIB ini terbagi menjadi beberapa segmen permainan diawali dengan TTS (Teka-Teki Sulit) dengan pilihan permainan seperti Cak Cik Boom, kuis psikologi, kuis peserta, kata misteri, dan lain-lain.

Keunikan yang ada dalam WIB menyebabkan adanya banyak tindak tutur ilokusi yang terjadi, seperti tuturan kejengkelan, tuturan pertanyaan, dan lain-lain. Oleh karena itulah, peneliti tertarik mengkaji permasalahan tentang bentuk-bentuk tindak tutur ilokusi dalam acara WIB pada episode 9 Juli 2018.

Berdasarkan uraian tersebut, maka tulisan ini bertujuan untuk mendeskripsikan bentuk-bentuk tindak tutur ilokusi dalam acara WIB pada episode 9 Juli 2018.

Adapun penelitian terdahulu yang terkait dengan tindak tutur ilokusi, antara lain penelitian yang dilakukan oleh Kurniati (2014) yang berjudul Tindak Tutur Ilokusi pada Pesan Singkat (SMS) Bermotif Penipuan. Penelitian ini membahas tentang tindak tutur ilokusi yang terdapat dalam pesan singkat (SMS) yang bermotif penipuan ada empat, yang mencakup tindak tutur asertif, ekspresif, direktif, dan deklaratif, sedangkan tindak tutur komisif tidak ditemukan dalam data. Selanjutnya, dibahas juga tindak tutur direktif yang terbagi menjadi dua, yaitu direktif langsung dan direktif tidak langsung. 
Penelitian lain yang juga mengkaji tentang tindak tutur ilokusi dilakukan oleh Mutji (2017) dengan judul Tindak Tutur Ilokusi Prof. J.E. Sahetapy dalam Talk Show ILC (Indonesian Lawyers Club) di TV One. Penelitian ini bertujuan untuk mengidentifikasi dan menganalisis fungsi tindak tutur ilokusi dan menentukan kesantunan tindak tutur ilokusi Prof Sahetapy dalam talk show ILC (Indonesian Lawyer Club) di TV One. Fungsifungsi ilokusi meliputi empat fungsi menurut konsep Leech, yaitu kompetitif (bersaing), konvivial (menyenangkan), kolaboratif (bekerja sama) dan konfliktif (bertentangan). Pembahasan selanjutnya tentang kaidah kesantunan ada tiga menurut Robin Lakoff, yaitu formalitas (formality), ketidaktegasan (hesitancy), dan persamaan atau kesekawanan (equality or camaraderie).

\section{LANDASAN TEORI}

\section{Tindak Tutur Ilokusi}

Menurut Widodo dan Sumarta (2016:52) tindak ilokusi adalah tindak tutur yang mengandung daya untuk melakukan sesuatu (an act of doing something saying something). Tindak ilokusi adalah tindak tutur yang mengandung maksud dan fungsi atau daya ujar. Tindak ilokusi tidak mudah diidentifikasi. Hal itu terjadi karena tindak ilokusi itu berkaitan dengan siapa bertutur kepada siapa, kapan, dan di mana tindak tutur dilakukan pada tindak tutur ilokusi perlu disertakan konteks tuturan dalam situasi tutur.

Tindak ilokusi dapat diidentifikasi sebagai tindak tutur yang berfungsi untuk menginformasikan sesuatu dan melakukan sesuatu. Secara konvensional yang berhubungan dengan setiap tindakan elokusioner adalah kekuatan ujaran yang dapat diungkapkan sebagai performatif seperti misalnya janji dan peringatan.

Leech (dalam Putrayasa, 2014:90) mengatakanbahwa fungsi sosial tindak ilokusi dapat dibagi menjadi empat jenis, sesuai dengan hubungan fungsi-fungsi tersebut dengan tujuan-tujuan sosial berupa pemeliharaan perilaku yang sopan dan terhormat. Berdasarkan pandangan tersebut, klasifikasi fungsi ilokusi Leech sebagai berikut. (1) Kompetitif (competitive), tujuan ilokusi yang bersaing dengan tujuan sosial, misalnya memerintah, meminta, menuntut, mengemis, dan menolak. (2) Menyenangkan (convival), tujuan ilokusi sejalan dengan tujuan sosial, misalnya menawarkan, mengajak atau mengundang, menyapa, mengucapkan terima kasih, dan mengucapkan selamat. (3) Bekerjasama (collaborative), tujuan ilokusi ini tidak menghiraukan tujuan sosial, misalnya menyatakan (menerima), menuntut, memaksakan, melapor, mengumumkan, menginstruksikan, dan mengajarkan. (4) Bertentangan (conflictive), tujuan ilokusi ini bertentangan dengan tujuan 
sosial, misalnya mengancam, menuduh, menyumpahi, menegur, mencerca, memarahi, dan mengecam. Dalam membicarakan perilaku linguistik yang sopan dan tidak sopan, perhatian hanya dipusatkan khusus pada ilokusi kompetitif dan ilokusi menyenangkan, dan pada kategori-kategori sopan santun yang negatif dan positif pada ilokusi-ilokusi tersebut.

Sebagai contoh, dalam hubungannya dengan fungsi sosial berupa pemeliharaan perilaku yang sopan dan terhormat, sebagai maksud atau tujuan personal, menurut Leech (dalam Putrayasa, 2014:90) tindak tutur direktif tergolong fungsi kompetitif atau bersaing dengan tujuan sosial. Tujuan-tujuan kompetitif itu pada dasarnya tidak bertata krama dan secara intrinsik tidak sopan dan cenderung menimbulkan konflik, misalnya memerintah, meminta, bertanya, bila disampaikan apa adanya cenderung memaksa. Tata krama dibedakan dengan sopan santun. Tata krama mengacu pada tujuan, sedangkan sopan santun mengacu pada perilaku linguistik atau perilaku lainnya untuk mencapai tujuan itu. Oleh karena itu, prinsip sopan santun dibutuhkan dalam penggunaan tindak tutur ini, untuk melemahkan atau memperlembut sifat tidak sopan yang secara intrinsik terkandung di dalam tujuannya. Hal itu dilakukan agar kedua belah pihak saling menghormati atau saling menguntungkan satu sama lain, tidak saling merugikan.

Sementara itu Searle (dalam Putrayasa, 2014:89) mengatakan bahwa berdasarkan fungsinya, tindak tutur ilokusi dapat dibedakan atas tindak tutur asertif, direktif, ekspresif, komisif, dan deklaratif. (1) Asertif: bermaksud menyampaikan sesuatu berkaitan dengan kebenaran preposisi atau pernyataan yang diungkapkan, misalnyamenyatakan menerima atau menolak, mengusulkan, membual, mengeluh, mengemukakan pendapat, melaporkan, menuntut, mengakui, menunjukkan, memberikan kesaksian, berspekulasi, dan menyebutkan. Tindak tutur asertif biasanya juga disebut dengan tindak tutur representatif. (2) Direktif: ilokusi ini bertujuan meminta lawan tutur melakukan sesuatu untuk menghasilkan suatu efek terhadap tindakan yang dilakukan oleh penutur; misalnya memesan, memerintahkan, memohon, meminta, mengundang, merekomendasikan, mengajak, memaksa, menyarankan, mendesak, menyuruh, menagih, menantang, menuntut, memberi aba-aba, dan memberi nasihat. (3) Komisif: ilokusi bertujuan untuk menyampaikan sesuatu yang terikat pada suatu tindakan di masa depan, misalnya menjanjikan atau berjanji, menawarkan mengancam, bersumpah, menyatakan kesanggupan, dan berkaul. (4) Ekspresif: fungsi ilokusi ini adalah mengungkap atau mengutarakan sikap psikologis penutur terhadap keadaan yang tersirat dalam ilokusi, misalnya mengucapkan terima kasih, mengucapkan selamat, memberi maaf, mengecam, memuji, mengucapkan belasungkawa, mengeluh, menyanjung, mengeluh, menyalahkan, 
dan mengkritik, dan sebagainya. (5) Deklarasi: fungsi ilokusi bertujuan untuk mengungkapkan pernyataannya yang keberhasilan pelaksananya tampak pada kesesuaian dengan realitas tindakan, misalnya mengundurkan diri, memecat, memberi nama, menjatuhkan hukuman, mengucilkan atau membuang, mengangkat,mengesankan, memutuskan, membatalkan, melarang, mengabulkan, mengizinkan, menggolongkan, mengampuni, menikahkan, membaptis, dan sebagainya.

Selain tindak tutur berdasarkan fungsinya, Searle (dalam Putrayasa, 2014:90) juga membagi tindak tutur berdasarkan maksud penutur ketika berbicara (ilokusi) menjadi lima jenis. Pembagian ini didasarkan atas asumsi "Berbicara menggunakan suatu bahasa adalah mewujudkan perilaku dalam aturan yang tertentu" kelima tindak tutur tersebut adalah sebagai berikut.

a. Tindak tutur representatif atau asertif, yaitu tindak tutur yang berfungsi untuk menetapkan atau menjelaskan sesuatu apa adanya. Tindak tutur ini, seperti menyatakan, melaporkan, memberitahukan, menjelaskan, mempertahankan, menolak, dan lain-lain. Tindak menyatakan dan mempertahankan maksudnya adalah penutur mengucapkan sesuatu, maka mitra tutur percaya terhadap ujaran penutur. Tindak melaporkan dan memberitahukan maksudnya ketika penutur mengujarkan sesuatu, maka penutur percaya bahwa telah terjadi sesuatu. Tindak menolak dan menyangkal maksudnya penutur mengucapkan sesuatu maka mitra tutur percaya bahwa ada alasan untuk tidak percaya. Tindak menyetujui dan mengakui maksudnya ketika penutur mengujarkan sesuatu, maka mitra tutur percaya bahwa apa yang diujarkan oleh penutur berbeda dengan apa yang ia inginkan dan berbeda dengan pendapat semula. Contoh:

1) Dosen: Pokok bahasan kita hari ini mengenai analisis wacana

Tuturan dosen tersebut merupakan salah satu contoh tindak tutur yang termasuk dalam tindak memberitahukan. Contoh (2):

A: "Tadi sebelum aku pulang dari kampus, aku lihat cowokmu sama cewek lain bermobil mewah. Sumpah!”

B: "Di mana?"

A: "Di belokan sepi belakang Rusunawa."

Kalimatpada tuturan A tersebut merupakan tindak ilokusi asertif. Pada kalimat tersebut A melaporkan kepada B, jadi kalimat pada tuturan tersebut adalah tindak ilokusi asertif yang berupa tindak melaporkan.

Melaporkan berarti memberitahukan; memberikan rencana pers. Melaporkan berarti memberitahukan ini tentunya kalimat yang digunakan berupa kalimat deklaratif. 
Kalimat deklaratif dalam bahasa Indonesia mengandung maksud memberitakan sesuatu kepada mitra tutur. Sesuatu yang diberitakan kepada mitra tutur itu lazimnya, merupakan suatu peristiwa atau suatu kejadian.

b. Tindak tutur komisif, yaitu tindak tutur yang berfungsi untuk mendorong pembicaraan melakukan sesuatu. Maksudnya, mengikat penutur untuk melaksanakan segala hal yang disebutkan dalam tuturannya. Yang termasuk dalam tindak komisif, yaitu menjanjikan atau berjanji, menawarkan, mengancam, bersumpah, menyatakan kesanggupan, dan berkaul. Tindak menjanjikan, mengutuk, dan bersumpah maksudnya adalah penutur menjanjikan mitra tutur untuk melakukan A, berdasarkan kondisi mitra tutur menunjukkan dia ingin penutur melakukan A. Contoh tindak ilokusi komisif pada tuturan berikut.

"Kalau kalian memilih saya, nantinya kalian akan saya traktir makan di KFC"

Kalimat tersebut dapat berupa tindak komisif menjanjikan. Tuturan tersebut menyatakan bahwa penutur akan melakukan tindakan pada masa mendatang dengan sebuah janji.

c. Tindak tutur direktif atau disebut juga tindak tutur imposif, tindak tutur yang berfungsi untuk mendorong pendengar atau mitra tutur untuk melakukan sesuatu. Maksudnya, tindak tutur yang dimaksudkan penuturnya agar si mitra tutur atau pendengar melakukan tindakan seperti yang disebutkan di dalam tuturan itu.Menurut Ibrahim (dalam Putrayasa, 2014:91) direktif mengekspresikan sikap penutur terhadap tindakan yang akan dilakukan oleh mitra tutur, misalnya memesan, memerintah, meminta, mengundang, merekomendasikan, mengajak, memaksa, bertanya atau menanyakan, menyarankan, mendesak, menyuruh, menagih, memohon, menantang, memberi abaaba, dan memberi nasihat. Tindak meminta maksudnya ketika mengucapkan sesuatu, penutur meminta mitra tutur untuk melakukan A, maksudnya mitra tutur melakukan A karena keinginan penutur. Tindak memerintah, maksudnya ketika penutur mengekspresikan keinginannya pada mitra tutur untuk melakukan A, mitra tutur harus melakukan A dan mitra tutur melakukan A karena keinginan penutur. Tindak bertanya, ketika mengucapkan sesuatu penutur bertanya, mengekspresikan keinginan kepada mitra tutur, mitra tutur menjawab apa yang ditanya oleh penutur.

Contoh (1) tindak ilokusi direktif:

Guru: siapa yang piket hari ini?

Siswa: Ani (siswa yang bersangkutan maju) 
Tuturan di atas merupakan suatu pertanyaan yang tujuannya meminta informasi mitra tutur.

Contoh (2):

Guru: Coba, ulangi jawabannya!

Tuturan ini juga termasuk tindak tutur direktif yang bermaksud menyuruh atau meminta mitra tutur mengulangi kembali jawabannya.

Contoh (3) tindak ilokusi direktif sebagai berikut.

"Dilla saya pesan majalah Tempo edisi bulan Desember ya!"

Tuturan tersebut merupakan tindak tutur direktif yang menunjukkan penutur sedang memesan majalah kepada mitra tutur. Pada tuturan itu penutur menginginkan suatu tindakan yang dilakukan oleh mitra tuturnya, dan pada contoh kalimat tersebut berupa tindakan untuk membelikan penutur majalah Tempo terbaru.

d. Tindak tutur ekspresif, yaitu tindak tutur yang berfungsi untuk mengekspresikan perasaan dan sikap. Secara lebih jelas, tindak tutur ekspresif adalah tindak tutur yang dilakukan oleh penutur dengan maksud ujaran yang disampaikan dapat diartikan mitra tuturnya sebagai sesuatu yang sedang dirasakan oleh penutur. Penutur mengekspresikan perasaan tertentu kepada mitra tutur baik yang berupa rutinitas maupun murni. Menurut Widodo dan Sumarta (2016:59) tuturan seperti itu dapat mencerminkan pernyataan-pernyataan seperti kegembiraan, kesenangan, kesulitan, kebencian atau pun kesengsaraan.

Beberapa jenis tindak tutur ekspresif adalah mengucapkan selamat, mengucapkan terima kasih, meminta maaf, memaafkan, mengecam, belasungkawa, mengeluh, menyanjung, memuji, mengeluh, menyalahkan, dan mengkritik. Dari beberapa jenis tersebut, penulis akan mengambil lima jenis untuk dipaparkan berikut ini.

1) Mengucapkan Selamat

Selamat berarti terpelihara dari bencana (berarti terhindar dari bahaya, aman, sentosa, sejahtera; tidak kurang suatu apa; sehat, tidak mendapat gangguan, kerusakandan sebagainya; beruntung; tercapai maksudnya; tidak gagal (Purwadarminta dalam Widodo dan Sumarta, 2016:59). Jadi yang dimaksud dengan mengucapkan selamat adalah mengungkapkan perasaan turut bergembira terhadap hal yang dicapai oleh seseorang. Contoh tindak ilokusi dapat dilihat pada tuturan berikut.

A: Selamat ya, kamu menjadi guru terbaik di sekolah ini.

$\mathrm{B}$ : terima kasih, $\mathrm{Bu}$. 
Pada contoh peristiwa tutur di atas nampak jelas bahwa tuturan tersebut termasuk tindak tutur ekspresif, yaitu mengucapkan selamat dan sekaligus tindak tutur mengucapkan terima kasih. Tuturan tersebut berupa ekspresi seorang guru pada guru lain yang berhasil menjadi guru terbaik di sekolah dengan mengucapkan selamat dan ekspresi guru yang menjawab dengan tuuran terima kasih.

2) Mengucapkan Terima Kasih

Terima kasih merupakan tuturan balasan yang digunakan oleh seseorang ketika ia mendapat sebuah ucapan dari orang lain. Ucapan terima kasih juga dapat digunakan untuk mengungkapkan rasa bahagia atas bantuan seseorang dan sebagainya. Contoh tuturan mengucapkan terima kasih sebagai berikut.

"Saya ucapkan terima kasih pada hadirin yang sudah datang di pestaku."

Pada kalimat tersebut terlihat bahwa tuturan tersebut merupakan tindak tutur ekspresif mengucapkan terima kasih, yakni rasa bahagia atas kehadiran tamu yang datang di pestanya.

3) Meminta maaf dan Memaafkan

Maaf adalah ungkapan ketika melakukan kesalahan yang telah diperbuat. Saat tuturan maaf (meminta maaf) diucapkan oleh penutur maka akan ada timbal balik dari mitra tutur, yaitu memberi maaf. Tindak tutur ini dapat dilihat pada contoh berikut.

A: Tok, maaf ya, kemarin tidak bisa hadir di pesta ulang tahun anakmu

B: ya, tidak apa-apa, Jok.

Tuturan pada kalimat di atas adalah tuturan seseorang yang meinta maaf karena tidak dapat hadir pada suatu acara. Pada contoh tersebut terlihat bahwa penutur mengucapkan maaf (meminta maaf) dan timbal balik dari mitra tutur adalah memaafkannya dengan berkata kepada penutur "tidak apa-apa" tidak hadir saat pesta dan dia memakluminya.

4) Mengecam

Mengecam yakni mengkritik atau mencela dengan menunjukkan mana yang baik dan mana yang salah. Mengecam adalah tuturan seseorang ketika ia menemukan hal-hal yang sangat tidak wajar (yang dilakukan seseorang). Contoh kalimat tuturan mengecam, sebagai berikut.

"Parfum yang kamu pakai sangat menyengat penciumanku!"

Tuturan tersebut diungkapkan oleh penutur untuk mengkritik atau mencela parfum yang digunakan mitra tuturnya dengan maksud meminta mitra tutur untuk memilih parfum yang digunakannya.

5) Belasungkawa 
Belasungkawa berarti berduka cita. Pernyataan belasungkawa dapat kita ungkapkan ketika seseorang yang kita kenal mendapat kemalangan (kematian) salah satu anggota keluarganya. Pernyataan belasungkawa ini merupakan ungkapan rasa simpati kita pada orang lain. Tuturan belasungkawa dapat dilihat pada contoh berikut.

"Bapak turut berduka cita atas berpulangnya ayahmu, Ndro".

Kalimat pada tuturan seorang ibu guru yang mengungkapkan rasa turut berduka cita atas meninggalnya ayah dari muridnya. Tuturan turut berduka cita merupakan bagian dari tuturan belasungkawa.

e. Tindak tutur deklaratif atau biasa juga disebut isbati, yaitu tindak tutur yang dimaksudkan penuturnya untuk menciptakan hal (status, keadaan, dsb.) yang baru. Tindak tutur deklaratif/isbati ini juga berfungsi untuk memantapkan sesuatu yang dinyatakan, antara lain dengan setuju, tidak setuju, benar-benar salah, dan sebagainya. Yang termasuk jenis tuturan deklaratif atau isbati adalah tuturan dengan maksud mengesankan, memutuskan, membatalkan, melarang, mengabulkan, mengizinkan, menggolongkan, mengangkat, mengampuni, menikahkan, membaptis, memecat, memberi nama, menjatuhkan hukuman, dan lain-lain. Contoh tindak tutur deklaratif:

"Pada hari ini kamu resmi saya angkat menjadi kepala bagian di kantor ini."

Kalimat pada tuturan di atas merupakan tindak tutur deklaratif berupa pengangkatan jabatan.

Searle (dalam Jumanto, 2017:70) juga berpendapat agar suatu tindak tutur berhasil dengan baik, penutur harus memenuhi syarat-syarat kondisi felisitas yang terdiri dari empat syarat, sebagai berikut.

(1) Makna proporsional (proportional content), yaitu kalimat yang diujarkan oleh penutur untuk menyatakan tindakannya,

(2) Syarat persiapan (preparatory condition), yaitu penutur harus memiliki otoritas atau kemampuan untuk melakukan tindakan dalam situasi kondisi tertentu,

(3) Syarat ketulusan (sincerety condition), yaitu penutur memiliki keyakinan atau perasaan tertentu sesuai dengan tindakan yang dia lakukan, dan

(4) Syarat lain yang perlu (essential condition), yaitu penutur melakukan tindakan tertentu yang dianggap perlu untuk mempertegas keyakinan atau perasaan yang dimilikinya.

\section{METODE PENELITIAN}


Penelitian tentang tindak ilokusi dalam acara WIB ini termasuk dalam penelitian deskriptif kualitatif. Menurut Sudaryanto (1992: 62) penelitian deskriptif dilakukan secara objektif hanya berdasarkan fakta atau fenomena yang secara empiris hidup pada penuturnya. Sedangkan menurut Sudjana dan Ibrahim (dalam Amar, 2010:53) penelitian deskriptif merupakan penelitian yang berusaha mendeskripsikan suatu gejala, peristiwa, dan kejadian yang menjadi pusat perhatiannya yang kemudian digambarkan sebagaimana mestinya.

Penelitian deskriptif mempelajari masalah dalam masyarakat, tata cara yang berlaku dalam masyarakat serta situasi-situasinya, sikap, pandangan, proses yang sedang berlangsung, serta pengaruh dari suatu fenomena. Dengan penelitian deskriptif dilakukan pengukuran yang cermat tentang fenomena dalam masyarakat. Peneliti mengembangkan konsep, menghimpun fakta tetapi tidak menguji hipotesis. Penelitian deskriptif juga dimaksudkan untuk mengumpulkan informasi mengenai status suatu gejala yang ada, yaitu keadaan gejala menurut apa adanya pada saat penelitian dilakukan (Arikunto dalam Amar, 2010:53). Tujuan penelitian deskriptif adalah untuk membuat penjelasan secara sistematis, faktual, dan akurat mengenai fakta-fakta, dan sifat-sifat populasi atau daerah tertentu. Menurut Zainuddin (dalam Amar, 2014:53) dalam penelitian deskriptif, tujuan penelitian adalah memperoleh gambaran dan deskripsi secara rinci, sistematis, dan akurat suatu fenomena. Rumusan tujuan penelitian deskriptif meliputi pengklasifikasian dan penguraian tentang sifat-sifat atau faktor-faktor fenomena tersebut.Jadi, penelitian ini berusaha untuk mendeskripsikan bentuk-bentuk tindak ilokusi dalam acara kuis WIB berdasarkan kajian pragmatik.

Objek penelitian ini adalah tindak ilokusi yang terdapat di dalam kuis WIB pada episode 9 Juli 2018 di Net TV. Menurut Sudaryanto (dalam Nadar, 2009:107) data adalah fenomena lingual khusus yang berkaitan langsung dengan masalah yang dimaksud. data penelitian ini adalah bentuk-bentuk tuturan tindak ilokusi dalam bentuk lisan yang diungkapkan oleh penutur dan mitra tutur (yang turut bermain di acara kuis WIB pada episode 9 Juli 2018). Bentuk tuturan dapat berupa tuturan saat penutur mengungkapkan kejengkelan, mengucapkan selamat, terima kasih, memerintah, dan bentuk tuturan lainnya, yaitu tuturan yang dipergunakan oleh penutur dan lawan tutur sewaktu berdialog, berinteraksi, dan berkomunikasi yang diperoleh sewaktu acara kuis tayang pada episode 9 Juli 2018. Sumber data bersifat tertulis, maksudnya data pertuturan yang direkam di Youtubekemudian ditranskripsikan dan ditulis dalam catatan. Hal itu juga penulis anggap sebagai data primer, yaitu transkripsi percakapan antara partisipan yang terlibat dalam 
pertuturan di acara kuis WIB. Sedangkan data sekunder penelitian ini berupa teori-teori yang relevan dengan penelitian tindak ilokusi yang didapatkankan dari kepustakaan juga dari internet. Penulis juga menjadi instrumen utama penelitian saat mengumpulkan data. Instrumen penelitian lainnya adalah laptop, headset, bolpoin, dan buku tulis.

Pengumpulan data penelitian ini menggunakan metode simak. Disebut metode simak karena cara yang digunakan untuk memperoleh data dilakukan dengan menyimak penggunaan bahasa, seperti menyimak pertuturan yang terjadi antarinforman. Metode simak ini memiliki teknik dasar yang berwujud teknik sadap. Mahsun (2007: 92) mengatakan bahwa teknik sadap merupakan upaya peneliti mendapatkan data yang dilakukan dengan menyadap penggunaan bahasa seseorang atau beberapa orang yang menjadi informan. Selanjutnya teknik sadap ini diikuti dengan teknik lanjutan yang berupa teknik simak bebas libat cakap, catat, dan teknik rekam. Teknik simak bebas libat cakap, maksudnya peneliti hanya berperan sebagai pengamat penggunaan bahasa oleh para informannya, jadi peneliti tidak terlibat dalam peristiwa pertuturan yang bahasanya sedang diteliti. Data penelitian ini berupa data lisan, maka teknik lanjutan selain teknik simak bebas libat cakap adalah teknik catat dan rekam. Saat menyimak pertuturan yang berlangsung antarinforman, peneliti mencatat penggunaan bahasa tersebut sambil merekam. Instrumen yang digunakan saat mencatat dan merekam adalah bolpoin, buku catatan, laptop, dan headset.

Analisis data dilakukan dengan menggunakan metode padan ekstralingual. Menurut Mahsun (2007: 117) padan merupakan kata yang bersinonim dengan kata banding dan sesuatu yang dibandingkan mengandung makna adanya keterhubungan sehingga padan diartikan sebagai hal menghubung-bandingkan. Pengertian ekstralingual mengacu pada makna yang dibedakan dengan unsur yang berada di luar bahasa, seperti hal-hal yang menyangkut makna, informasi, konteks, tuturan, dan lain-lain. Jadi metode padan ekstralingual ini digunakan untuk menganalisis unsur yang bersifat ekstralingual, seperti menghubungkan masalah bahasa dengan hal yang berada di luar bahasa. Teknik dasar metode padan yang digunakan adalah teknik hubung banding yang bersifat ekstralingual maksudnya menghubung-bandingkan hal-hal yang di luar bahasa seperti tindak tutur dan konteks tuturan. Tahapan analisis datanya, penulismendengarkan rekaman video WIB di youtube, kemudian ditranskripsikan, dicatat, dianalisis datanya, diberi kode berdasarkan teori, melihat hubungan dan membandingkan perbedaan teori dengan hasil analisis. Teknik analisis data yang digunakan adalah teknik hubung banding menyamakan hal pokok (HBSP), yaitu teknik yang bertujuan untuk mencari kesamaan hal pokok dari 
pembedaan dan penyamaan yang dilakukan dengan menerapkan teknik HBS (Hubung banding menyamakan) dan teknik HBB (Hubung banding membedakan). Tujuan akhir dari banding menyamakan atau membedakan tersebut adalah menemukan kesamaan pokok di antara data yang diperbandingkan itu. Teknik HBSP lebih bersifat ekstralingual, menghubungbandingkan bentuk bahasa (tindak ilokusi) dengan hal di luar bahasa, maksudnya penggunaan bahasa berdasarkan konteksnya.

\section{PEMBAHASAN}

Berdasarkan data tindak ilokusi dalam acara WIB pada episode 9 Juli 2018 di Net TV, bentuk-bentuk tindak tutur ilokusi akan dibahas menurut teori Searle, yang membagi tindak ilokusi menjadi lima jenis. Kelima jenis tindak ilokusi berdasarkan Searle adalah sebagai berikut:1) asertif/representatif; 2) komisif; 3) direktif/imposif; 4) ekspresif; dan 5) deklaratif/ isbati.

Adapun para partisipan pertuturan dalam acara kuis WIB, diberi kode-kode untuk namanya. Kode nama tersebut adalah Cak Lontong (CL), Nabila Putri (NP), Akbar (Ak), Agung Hercules (Ah), Peppy (P), Bedu (B), Deni Chandra (Dc), Hana Prinantina (H), dan Kang Dagang $(\mathrm{Kd})$. Berikut ini pembahasan mengenai tindak tutur ilokusi dalam acara Kuis WIB episode 9 Juli 2018 di Net TV yang ditemukan berdasarkan hasil penelitian.

\section{a. Tindak tutur representatif atau asertif}

Tindak tutur representatif atau asertif, yaitu tindak tutur yang berfungsi untuk menetapkan atau menjelaskan sesuatu apa adanya. Tindak tutur ini, seperti menyatakan, melaporkan, memberitahukan, menjelaskan, mempertahankan, menolak, menuntut, menunjukkan, melaporkan, berspekulasi, mengakui, memberikan kesaksian, dan lain-lain.

\section{Memberitahukan}

Konteks: NP selaku pemandu acara sedang memberitahukan kepada penonton tentang siapa saja yang akan bermain di tim A dan tim B

NP : Tim A ini sudah ada Agung Hercules dan Bedu, berikan tepuk tangan! Dan tidak lupadi tim B ada Kang Deny dan Hana Prinantina

Berdasarkan tuturan NP Tim A ini sudah ada Ah dan B, dan tidak lupa di tim B ada kang $D c$ dan $H$ merupakan bentuk tindak tutur representatif, yaitu tindak lokusi memberitahukan.

\section{Menjelaskan}

Konteks: NP sedang menjelaskan kepada penonton maupun pemirsa di rumah tentang cara menjawab pertanyaan kuis TTS WIB 
NP : ....Cak, untuk TTS WIB sudah ada pertanyaan-pertanyaan baru dan bisa langsung di download di appstore dan juga di google play sekarang juga, resmi dari net media, namanya wibttscaklontong.

Tuturan NP di atas merupakan bentuk tindak tuturrepresentatif, yaitu tindak lokusi menjelaskan kepada pemirsa di rumah. Penjelasan tersebut diikuti dengan caranya pemirsa bergabung menjawab pertanyaan kuis WIB yang harus diunduh dahulu di internet.

\section{Menolak}

Konteks: Kd sedang berjualan barang yang dapat dibayar kredit dengan dicicil 3x pagi, siang, malam. Saat itu B bertanya alasannya tidak membawa motor untuk dijual.

Kd : ngreditin barang apa aja bisa, yang dibawa aja, sebenarnya mo bawa motor tapi kan berat.

Tuturan Kd "mo bawa motor tapi kan berat" merupakan bentuk tindak tutur representatif, yaitu tindak ilokusi menolak dengan alasan membawa motor untuk dijual jelas berat, oleh karena itulah Kd tidak mau membawa motor untuk dijual.

\section{Menuntut}

Konteks: Ak dan CL menuntut B untuk menceritakan asal mula kejadian dia protes.

Ak : Emang kejadiannya gimana? Heh, gimana kejadiannya?

CL : Awalnya gimana kejadiannya?

Tuturan Ak dan CL yang menanyakan kepada B untuk menceritakan kejadian yang dialami B.Tuturan pertanyaan dari Ak dan CL tersebut merupakan bentuk tindak tutur representatif, yaitu tindak lokusi menuntut seseorang sesegera mungkin bercerita tentang suatu kejadian.

\section{Mengakui}

Konteks: B mengakui bahwa penonton setuju dengan jawaban dari CL karena sudah tahu jawaban yang sebenarnya.

B : Iya, karena Anda sudah tahu kejadiannya!

Tuturan B “Iya, karena Anda sudah tahu kejadiannya!” merupakan pengakuannya bahwa penonton sudah tahu jawaban dari CL yang sebenarnya sehingga setuju-setuju saja dengan CL, tidak mau protes.

\section{Melaporkan}

Konteks: B melaporkan kepada semua orang di WIB tentang asal mula kejadian yang B maksud. 
B : Kejadiannya sih, awalnya coba-coba.

Tuturan B kepada semua orang di WIB adalah bentuk tindak tutur representatif, yaitu tindak ilokusi melaporkan. Namun, hal yang dilaporkan oleh B itu bukanlah laporan dari kejadian yang sebenarnya, B hanya mengalihkan topik dari protes jawaban menjadi komedi dengan topik lain.

\section{Memberi Kesaksian}

Konteks: B memberikan kesaksian kepada orang-orang bahwa yang mengajak dia menjadi pelayan kafe adalah pamannya.

CL : Yang ngajak siapa itu?

B : Yang pertama ngajak sih paman saya!

Tuturan B "Yang pertama ngajak sih paman saya!" adalah kesaksian dari B karena salah bekerja menjadi pekerja kafe. Bentuk tuturan B tersebut merupakan bentuk tindak tutur representatif, yaitu tindak ilokusi memberi kesaksian.

\section{b. Tindak tutur komisif}

Tindak tutur komisif yaitu tindak tutur yang berfungsi untuk mendorong pembicaraan melakukan sesuatu. Yang termasuk dalam tindak komisif, yaitu menjanjikan atau berjanji, menawarkan, mengancam, bersumpah, menyatakan kesanggupan, dan berkaul atau bernazar.

\section{Menjanjikan}

Konteks: NP menjanjikan kepada pemirsa di rumah yang ikut kuis instagram dan menjawabnya akan mendapat hadiah.

NP : ...Cak, kita juga punya hadiahuntuk pemirsa yang ada di rumah untuk kuis instagram.

CL : ...Nah, itu nanti akan ada hadiah 500 ribu rupiah bagi kalian yang berhasil menjawab cepat dan tepat.

Tuturan NP dan CL tentang "hadiah 500 ribu rupiah bagi pemirsa" merupakan bentuk tindak tutur komisif, yaitu tindak ilokusi menjanjikan hadiah berupa uang.

\section{Menawarkan}

Konteks: Kd datang sambil membawa barang untuk ditawarkan kepada semua orang di WIB dengan sistem kredit dan bisa dicicil.

CL : ini saya bawa barang-barang yang bisa dibeli kredit dan bisa juga dicicil pagi, siang, dan malam 
Tuturan Kd "saya bawa barang-barang yang bisa dibeli kredit dan bisa juga dicicil" merupakan bentuk tindak tutur komisif, yaitu tindak ilokusi menawarkan barang dagangan kepada para partisipan kuis WIB.

\section{Mengancam}

Konteks: CL mengancam tim kompor tidak akan menghitung sebagai penonton apabila posisi mereka sedang merem (tutup mata).

Ak : Kita dihitung penonton gak, nih?

CL :Tergantung kalau Anda pas merem, gak dihitung!

Tuturan CL “Tergantung kalau Anda pas merem, gak dihitung!" adalah ancaman untuk tim kompor agar tidak menutup matanya, sebab kalau mereka sampai merem (tutup mata) dianggap oleh CL bukan penonton. Tuturan CL itu merupakan bentuk tindak tutur komisif, yaitu tindak ilokusi mengancam.

\section{c. Tindak tutur direktif atau imposif}

Tindak tutur yang dimaksudkan penuturnya agar si mitra tutur atau pendengar melakukan tindakan seperti yang disebutkan di dalam tuturan itu. Tindakan yang akan dilakukan oleh mitra tutur, misalnya memesan, memerintah, meminta, mengundang, merekomendasikan, mengajak, memaksa, bertanya atau menanyakan, menyarankan, mendesak, menyuruh, menagih, memohon, menantang, memberi aba-aba, dan memberi nasihat.

\section{Bertanya}

Konteks: CL memberikan pertanyaan untuk dijawab oleh peserta kuis.

CL : Gampang sekali pertanyaannya "contoh kata tanya untuk menunjukkan kata ganti orang...?"

Tuturan CL “contoh kata tanya untuk menunjukkan kata ganti orang...?" merupakan bentuk tindak tutur direktif/imposif, yaitu tindak ilokusi bertanya sebuah pertanyaan kepada para peserta WIB untuk menjawabnya.

\section{Memerintah}

Konteks: Ah dan Dc memberi perintah kepada B saat mendapat hukuman untuk berdiri pada posisi yang tepat.

Ah : Geser dikit, eh cukup!

Dc : Eh, mundur sedikit, Du!

Tuturan Ah dan Dc kepada B untuk mengatur posisi berdirinya saat terkena hukuman merupakan bentuk tindak tutur direktif, yaitu tindak ilokusi memerintah.

\section{Menyarankan}


Konteks: Tim Kompor yang terdiri dari Ak dan P memberikan saran kepada tim A dan B yang salah memberikan jawaban atas pertanyaan kuis dari CL.

Ak : Kenapa gak suami?

$\mathrm{P}$ : Kata ganti orang, kan?

Ak : suami bisa atau si Umi juga bisa!

Tuturan Ak dan $\mathrm{P}$ tersebut di atas kepada tim A dan tim B sebenarnya dapat memberikan jawaban "suami atau si Umi” untuk pertanyaan dari CL, siapa tahu betul, merupakan bentuk tindak tutur direktif, yaitu tindak ilokusi menyarankan.

\section{Memberi Aba-aba}

Konteks: NP memberi aba-aba kepada tim A untuk segera menjawab pertanyaan sebelum waktu habis.

$\mathrm{NP}: 3,2,1$

Tuturan NP menghitung dengan angka 3 mundur ke angka 1 tersebut merupakan bentuk tindak tutur direktif, yaitu memberi aba-aba kepada tim A untuk segera berpikir dan memberikan jawaban sebelum waktu yang diberikan habis.

\section{Menyuruh}

Konteks: CL menyuruh kepada B yang sedang emosi atau marah untuk belajar mengatur emosi.

\section{CL: Sekarang diatur emosi, tahan nafas dulu, diatur nafasnya dulu!}

Tuturan CL kepada B berupa cara untuk mengatur emosi merupakan bentuk tindak tutur direktif, yaitu tindak ilokusi menyuruh.

\section{Memberi nasihat}

Konteks: Dc memberi nasihat kepada B tentang bahayanya terlalu emosi dengan kata-kata yang mengandung unsur lucu.

Dc : Kalau lu marahnya ketinggian, bisa pecah pembuluh ketek!

NP : Pembuluh darah!

Tuturan Dc kepada B yang sedang emosi sekali merupakan bentuk tindak tutur direktif, yaitu tindak ilokusi memberi nasihat.

\section{d. Tindak tutur ekspresif}

Tindak tutur ekspresif, yaitu tindak tutur yang berfungsi untuk mengekspresikan perasaan dan sikap. Beberapa jenis tindak tutur ekspresif adalah mengucapkan selamat, mengucapkan terima kasih, meminta maaf, memaafkan, mengecam, belasungkawa, mengeluh, menyanjung, memuji, mengeluh, menyalahkan, dan mengkritik.

\section{Mengucapkan Selamat}


Konteks: NP mengawali acara kuis WIB dengan mengucapkan selamat kepada para pemirsa di studio maupun di rumah.

NP :Selamat malam, pemirsa, kita berjumpa lagi di WIB, Waktu Indonesia Bercanda.

Tuturan NP saat mengucapkan "selamat malam pemirsa" kepada seluruh pemirsa yang sedang menonton WIB merupakan bentuk tindak tutur ekspresif, yaitu tindak ilokusi mengucapkan selamat namun dengan bentuk sapaan.

Selain bentuk contoh mengucapkan selamat dengan bentuk sapaan juga ada data mengucapkan selamat dengan bentuk berbeda, sebagai berikut.

Konteks: NP mengucapkan selamat kepada para pemenang kuis WIB di instagram. NP : Selamat kepada pemenang kuis WIB di instagram, jangan lupa hadiah dipotong pajak.

Tuturan NP yang menuturkan "selamat bagi pemenang kuis instagram" merupakan bentuk tindak tutur ekspresif, yaitu tindak ilokusi mengucapkan selamat.

\section{Mengucapkan Terima Kasih}

Konteks: NP mengucapkan terima kasih ketika acara akan berakhir kepada semua pengisi acara WIB dan pemirsa.

NP : Terima kasih Hana, terima kasih untuk seluruh pengisi acara WIB

Tuturan NP saat berterima kasih kepada peserta artis yang diundang dan semua pengisi acara WIB, tentunya juga secara tersirat ucapan terima kasih untuk semua pemirsa WIB. Tuturan NP tersebut merupakan bentuk tindak tutur ekspresif, yaitu tindak ilokusi mengucapkan terima kasih.

\section{Mengeluh}

Konteks: CL mengeluh karena peserta mencurigai dia akan memberikan pertanyaan dan jawaban yang susah diterima logika lagi.

CL : Saya dicurigai lagi, yang lari-lari Mamat, yang baca buku Budi, yang nyanyinyanyi Wawan, saya nggak sekelas dengan mereka, saya mesti bagaimana?

Tuturan CL saat dicurigai peserta merupakan bentuk tindak tutur ekspresif, yaitu tindak ilokusi mengeluh kepada peserta.

\section{Mengecam}

Konteks: Ah mengecam CL selaku pemandu acara yang harus mengajukan pertanyaan namun sering tidak jelas pertanyaan atau pernyataan saat diajukan pada peserta.

Ah : Dia suka menjebak soalnya, nggak ada pertanyaan, kadang-kadang pernyataan. 
Tuturan Ah "Dia suka menjebak soalnya" kepada CL merupakan bentuk tindak tutur ekspresif, yaitu tindak ilokusi mengecam. CL menganggap tuturan Ah sebagai kecaman karena ia merasa tidak dipercaya oleh peserta yang selalu menyalahkannya.

\section{Menyanjung}

Konteks: CL menyanjung tim kompor yang terdiri dari Ak dan P saat diperkenalkan kepada pemirsa.

CL : dan tidak lupa saudara tim kompor yang terdiri dari part duo yang tidak terpecahkan.

Tuturan CL yang memperkenalkan tim kompor dengan part duo yang tidak terpecahkan dimaknai anggota tim yang benar-benar solid. Tuturan CL merupakan bentuk tindak tutur ekspresif, yaitu tindak tutur menyanjung.

\section{Memuji}

Konteks: Dc memuji tim A yang memutuskan piliha pada angka kecil untuk memilih pertanyaan.

Dc : Kalian ini luar biasa ya? Badannya gede-gede tapi angkanya kecil-kecil

Tuturan Dc "Kalian ini luar biasa" merupakan bentuk pujian kepada tim A, namun pujian yang mengarah negatif bukan positif, tetapi pujian olok-olok. Tuturan Dc tersebut merupakan bentuk tindak tutur ekspresif, yaitu tindak ilokusi memuji.

\section{Menyalahkan}

Konteks: CL merasa bahwa para peserta selalu menyalahkan dia karena tidak jelas pertanyaannya

CL : Kurang jelas pertanyaannya? Jam 7 pagi, saya bilang, astaghfirullah bisa tidak menyalahkan saya?, orang sudah jelas, jam 7 pagi pertanyaannya, baca soal salah, tidak baca salah juga.

Tuturan CL "Bisa tidak menyalahkan saya" adalah ungkapan murni dari lubuk hati karena merasa peserta tidak mempercayainya, sehingga dia harus menegaskan soal jam 7 pagi. Tuturan CL itu merupakan bentuk tindak tutur ekspresif, tindak ilokusi menyalahkan.

\section{Mengkritik}

Konteks: CL mengkritik Ah dan B yang disuruh memilih angka tetapi ribut saat menyebutkan hasil dari pengurangan angka tersebut.

Ah : Jangan! Mending 2-1

B : 7 kalo gitu

CL : Hei, bisa hitung-hitungan gak, sih! 
Tuturan CL "hei, bisa hitunga-hitungan gak, sih!” merupakan kritikan untuk Ah dan B yang tidak bisa menghitung dengan benar hasil dari 2-1. Tuturan CL tersebut merupakan bentuk tindak tutur ekspresif, yaitu tindak ilokusi mengkritik.

\section{e. Tindak Tutur deklaratif atau isbati}

Tindak tutur deklaratif atau biasa juga disebut isbati, yaitu tindak tutur yang dimaksudkan penuturnya untuk menciptakan hal (status, keadaan, dsb.) yang baru. Yang termasuk jenis tuturan deklaratif atau isbati adalah tuturan dengan maksud mengesankan, memutuskan, membatalkan, melarang, mengabulkan, mengizinkan, menggolongkan, mengangkat, mengampuni, menikahkan, membaptis, memecat, memberi nama, dan menjatuhkan hukuman.

\section{Memutuskan}

Konteks: Dc bertanya kepada $\mathrm{H}$, teman setimnya, untuk memutuskan jawaban yang diberikan atas pertanyaan dari CL

Dc : sulit atau suami?

$\mathrm{H}$ : sulit

Dc : sulit

Tuturan H dan Dc menjawab "sulit" adalah bentuk keputusan final setelah dirundingkan bersama mengenai jawaban yang menurut mereka tepat atas pertanyaan dari CL. Tuturan H dan Dc merupakan bentuk tindak tutur deklaratif, yaitu tindak ilokusi memutuskan.

\section{Melarang}

Konteks: Ah melarang B yang mempermasalahkan pertanyaan dianggap sebuah pernyataan dengan memberi contoh CL.

Ah : Jangan keterlaluan, Du! Aduuh..(ada bunyi sebagai tanda hukuman untuk B)

Tuturan Ah “Jangan keterlaluan, Du!” karena ulah B yang memberikan kalimat dengan menyebut nama CL, yang menurutnya itu tidak sopan dan mungkin juga melanggar kode etik.

\section{Mengizinkan}

Konteks: CL mengizinkan tim B untuk giliran menjawab pertanyaan

CL : Silahkan tim B!

Tuturan CL "silahkan tim B" memberikan kesempatan kepada tim B untuk menjawab pertanyaan. Tuturan CL merupakan bentuk tindak tutur deklaratif, yaitu tindak ilokusi mengizinkan.

\section{Menjatuhkan hukuman}


Konteks: Di WIB ada sesi hukuman bagi peserta yang sangat emosi dengan berbicara di pelantang, namun pelantang tersebut tidak berbunyi normal, melainkan saat peserta bicara jadi suara kecil dan aneh.

CL : (menyodorkan mic, B terkena hukuman karena marah) Silahkan, Anda tahu treatment ini sama buka puasa toh?

Tuturan CL menyamakan hukuman dengan treatment yang tidak berlaku saat tayang di bulan puasa saja, namun tetap berlaku hukuman yang sama setelah bulan puasa berakhir. Perlakuan hukuman memakai mic itu dimaksudkan agar peserta yang emosi menjadi turun emosinya setelah mendengar suaranya sendiri yang aneh, dan peserta bisa tertawa kembali. Tuturan CL tersebut merupakan bentuk tindak tutur deklaratif, yaitu tindak ilokusi menjatuhkan hukuman.

\section{SIMPULAN}

Tindak tutur ilokusi menurut konsep Searle ditemukan dalam data kuis WIB episode 9 Juli 2018. Data tersebut dapat dikategorikan ke dalam lima jenis tindak ilokusi, yaitu 1) representatif; 2) komisif; 3) direktif; 4) ekspresif; dan 5) deklaratif.

Ada tujuh data yang dapat dikategorikan dalam tindak ilokusi representatif, yaitu tindak ilokusi memberitahukan, menjelaskan, menolak, menuntut, mengakui, melaporkan, dan memberi kesaksian. Cara partisipan (pengisi acara WIB) menuturkan lebih banyak dalam hal pertanyaan yang dianggap sebagai pernyataan oleh peserta maupun jawaban yang dianggap peserta tidak sesuai dengan logika. Berdasarkan tindak tutur asertif yang mengharuskan penuturnya mengatakan kebenaran atas apa yang diujarkan ada yang sesuai seperti peserta yang menuntut kebenaran jawaban. Sedangkan CL dianggap tidak memberikan jawaban yang sesuai dengan logika dan kebenaran.

Tindak ilokusi komisif pada acara kuis WIB ditemukan ada tiga data, yaitu tindak ilokusi menjanjikan, menawarkan, dan mengancam. Berdasarkan tujuan tindak tutur komisif yang mengharuskan penuturnya melaksanakan hal yang disebutkan dalam ujaran apabila dianalisis dengan datanya, terlihat bahwa penutur melaksanakan segala hal yang ia sebutkan dalam tuturan.

Bentuk tindak tutur ilokusi direktif ada enam data yang ditemukan, yaitu tindak ilokusi bertanya, memerintah, menyarankan, memberi aba-aba, menyuruh, dan memberi nasihat. Tindak tutur direktif yang dimaksudkan penutur agar si pendengar melakukan tindakan yang disebutkan dalam tuturan itu. Hal ini sesuai dengan hasil analisis bahwa saat penutur menyuruh sesuatu, si pendengar atau mitra tutur melakukan apa yang 
diperintahkan. Hanya ada satu data, yaitu memberi nasihat yang dilakukan Dc kepada B yang ia alihkan dalam bentuk komedi, seperti pembuluh darah dibilang pembuluh ketek.

Hasil data paling banyak ditemukan pada tindak tutur ilokusi ekspresif, karena dalam kuis WIB ini banyak ungkapan hati dari peserta maupun pemandu acara yang diekspresikan dalam bentuk tuturan. Tujuan tindak tutur ekspresif yang menuntut penutur mengeluarkan sikap dan perasaan saat pertuturan berlangsung dapat tercapai. Adapun bentuk tindak tutur ilokusi ekspresif yang ditemukan ada delapan data, yaitu tindak ilokusi mengucapkan selamat, mengucapkan terima kasih, mengeluh, mengecam, menyanjung, memuji, menyalahkan, dan mengkritik.

Terakhir, tindak tutur deklaratif diwujudkakn dengan pernyataan penutur yang dimaksudkan untuk menciptakan hal (status, keadaan, dsb) yang baru. Penutur menciptakan hal atau keadaan yang baru di WIB dengan cara memutuskan, melarang, mengizinkan, dan menjatuhkan hukuman. Hal yang terlihat perubahan adalah saat B diberi hukuman berbicara di mic akibat terlalu emosi, ternyata B langsung turun emosinya dan justru melucu agar orang lain tertawa dengan mengalihkan topik pembicaraan.

\section{DAFTAR PUSTAKA}

Amar, Noezafri. 2010. "Praanggapan dan Implikatur pada Wacana Lisan dalam Acara Mata Najwa di Metro TV”. Madah, 1 (1): 49-60.

Chaer, Abdul. 2007. Kajian Bahasa: Struktur Internal, Pemakaian dan Pemelajaran. Jakarta: Rineka Cipta

Mutji, Elsye Jesti. 2017. “Tindak Tutur Ilokusi Prof. J.E. Sahetapy dalam Talk Show ILC (Indonesia Lawyers Club) di TV One”. Gramatika V (2): 90-101.

Jumanto. 2017. Pragmatik: Dunia Linguistik Tak Selebar Daun Kelor Edisi 2. Yogyakarta: Morfalingua

Kurniati, Ai. 2014. "Tindak Tutur Ilokusi pada Pesan Singkat (SMS) Bermotif Penipuan”. Suar Betang, IX (1): $67-75$.

Mahsun. 2007. Metode Penelitian Bahasa: Tahapan Strategi, Metode, dan Tekniknya Edisi Revisi. Jakarta: PT Raja Grafindo Persada

Putrayasa, Ida Bagus. 2014. Pragmatik. Yogyakarta: Graha Ilmu

Wahdati, Zahratul. 2016. Makalah Analisis Wacana Humor dalam Acara Waktu Indonesia Bercanda. (online). (https://www.plukme.com/post/1528645614-makalahanalisis-wacana.com. diakses 25 Juni 2018) 
Widodo, Mulyanto \& Sumarta, I Wayan Ardi. 2016. Prinsip Percakapan: Pengantar Pemahaman Santun Berbahasa. Yogyakarta: Textium

Wikipedia bahasa Indonesia, ensiklopedia bebas (online).

(https://id.wikipedia.org/wiki/Waktu-Indonesia-Bercanda. diakses 25 Juni 2018) 